\title{
Coleoptera of Poultry Manure in Caged-layer Houses in North Carolina ${ }^{1}$
}

\author{
D. G. PFEIFFER ${ }^{2}$ AND R. C. AXTELL \\ Dept. of Entomology, North Carolina State Univ., Raleigh 27650
}

ABSTRACT

Environ. Entomol. 9: 21-28 (1980)

At least 120 species of Coleoptera were recovered from poultry manure in narrow, widespan, and high-rise types of caged-layer poultry houses in the Mountains, Piedmont, and Coastal Plain regions of North Carolina. Carcinops pumilio (Erichson) and Alphitobius diaperinus (Panzer) were consistently the most abundant species in all 3 regions, followed by Gnathoncus nanus (Scriba) and the Aleocharinae (Staphylinidae). According to 5 indices of diversity, the Piedmont ranked 1 st in overall diversity, species richness and equitability, followed by the Coastal Plain, and thirdly, by the Mountains.

Narrow and high/rise house types were compared for adult and larval $C$. pumilio and $A$. diaperinus. The larval population peak for $A$. diaperinus occurred significantly earlier in the high-rise than in the narrow houses, however, the narrow houses had significantly higher beetle diversity.

A qualitative examination of overwintering forms showed that most species overwintered primarily, but not exclusively, as adults.

One of the major problems in poultry production is that of flies produced in the accumulating manure. House flies (Musca domestica L.) are of primary importance, because of their seemingly ubiquitous distribution on poultry farms, and their synanthropic nature, part of which involves their frequenting man's dwellings. Many species of beetles are known or suspected predators of the immature stages of the house fly and consequently are thought to be important biological agents suppressing fly populations.

Although many beetle species have been recorded from a variety of types of manure only a few studies in limited geographic areas have focused on the Coleoptera of poultry manure. Legner and Olton (1970) reported a worldwide survey of adult predator and scavenger insect populations of many types of domestic animal manure (including poultry), with some sampling in the Neotropical, Palearctic, Ethiopian, and Australian regions, but mostly California and the southwestern United States. However, seasonal effects in the worldwide study were entirely neglected, and the only distinction made in the California study was that between summer and winter. Toyama and Ikeda (1976b) surveyed fly predators in 6 poultry farms on the Hawaiian island of Oahu; however, they gave little consideration to seasonal effects, except to note that there were different seasonal variations in different parts of the island. Peck and Anderson (1969) surveyed predatory beetles in poultry manure on 2 farms in northern California and included data on seasonal variation with samples taken weekly or biweekly from June to the following April. In southern California, Leg. ner et al. (1975) examined seasonal and regional effects on the beetle fauna of poultry manure by comparing a farm in the coastal area with one in the interior. Legner (1965) studied the arthropods associated with $M$. domestica in Puerto Rico, in a variety of types of animal manure (including one poultry farm) and found that parasites and predators significantly reduced fly numbers.

1 Paper No. 6097 of the Journal Series of the North Carolina Agric. Research Service. Received for publication Sept. 4, 1979

Dept, of Entomology. Washington' State Univ., Pullman 99164
Due to the lack of data on the incidence of beetles in poultry manure in the eastern United States and the importance of some species of beetles as predators of the immature stages of the house fly, we conducted a systematic survey of the beetle fauna in the manure of caged-layer poultry houses in the 3 regions (Mountain, Piedmont, and Coastal Plain) of North Carolina.

\section{Materials and Methods}

Five poultry farms were sampled in each of the 3 regions of North Carolina: Mountains (Wilkes and Davie Co.) Piedmont (Alamance, Orange, and Chatham Co.) and Coastal Plain (Craven and Lenoir Co.). Three types of caged-layer poultry houses were included in the survey: narrow, wide-span (Mountain region only) and high-rise (Piedmont region only). The narrow houses ("California-type") were open-sided (30-90 m long $\times$ $3 \mathrm{~m}$ wide; $1500-5000$ bird capacity) with one row of 2 tiered wire stairstep cages, 2 or 3 birds/cage, suspended $1-1.5 \mathrm{~m}$ above a dirt floor and running the length of the house along each side of a single concrete aisle. Widespan houses were open-sided $(60-90 \mathrm{~m}$ long $\times 6-9 \mathrm{~m}$ wide; $8000-12,000$ bird capacity) with one row of 2 tiered wire stairstep cages, 2 or 3 birds/cage, suspended above a dirt or concrete floor and running the length of the house along each side of $3-4$ concrete aisles. Highrise houses, sometimes called deep-pit houses, were 2story, (122-152 m long $\times 9-12 \mathrm{~m}$ wide; $20,000-25,000$ bird capacity) with the birds held on the open sided 2 nd story in rows of 3-or 4-tiered wire stairstep cages which ran the length of the house along each side of 3-4 wooden aisles and the manure accumulated on the dirt bottom of the 1st floor. Data from all house types were combined in all analyses except for comparison of house types.

Manure samples were taken monthly (Apr. - Nov., 1977) resulting in 8 sampling dates in the Mountains and Piedmont, and 7 in the Coastal Plain (Apr. omitted). In the Piedmont, only 2 of the farms were sampled in Apr. Two houses per farm were sampled (with the exception of 2 farms in the Mountains having only one house each), and 5 samples were taken/house. The depth of the 
manure in the narrow and wide-span houses averaged $30-50 \mathrm{~cm}$, depending on the degree of dryness and coning at the sampling times and the manure was partially removed once or twice a year. The manure (ca. $50 \mathrm{~cm}$ deep) in the high-rise houses had accumulated for ca. a year and was not removed during this survey. Samples were taken equidistantly along both sides of a house as far as was practical. A sample consisted of 1.9-2.5 liters of manure gathered in a single location with a hand trowel, and placed in a 3.8-liter cardboard ice cream container lined with a plastic bag. The top edge of the bag was turned down over the rim of the container before the cover was put on, to prevent the accumulation of condensation, and to allow air exchange. The samples of manure were placed in Tullgren funnels upon a screen insert ( $35 \mathrm{~cm}$ diam, 6.3-mm mesh openings). A $60-\mathrm{W}$ bulb and reflector on top of each funnel served as the heat-light source to drive the insects downward into a jar containing $70 \%$ ethanol. Samples were left on the funnels until dry $(72-96 \mathrm{~h})$. After the extraction period, the contents of the jars were transferred to 150 -ml plastic jars, where they were held for counting and species identification. Counts were made under a binocular dissecting microscope.

The SAS General Linear Models (GLM) procedure (Barr et al. 1976) was used for the analysis of variance among the regions, among the farms in a region, and between house types. Duncan's multiple range test, as amended by Helwig (1977), was used to compare the region means. The values for $H^{\prime}$ in the diversity comparisons were tested for significance with a $t$ test as described by Poole (1974).

To determine what species and stages of beetles were overwintering in the poultry manure in the caged-layer houses, selected farms were sampled in Jan. and Mar.: 3 farms in the Mountain region, 4 in the Piedmont, and 2 in the Coastal Plain. One to 3 manure samples (6-7 liters each) were taken/farm. The purpose of the larger sample size was to allow the sample to extend from the manure surface to the ground surface below the manure bed, in an effort to find the overwintering individuals which may have burrowed deeper into the substrate. Since Tullgren funnels are only effective in sampling motile organisms, it was feared that their use would preclude the discovery of dormant forms. Therefore, handsorting under a magnifier with flourescent illumination was employed.

\section{Results and Discussion}

\section{Species Composition}

Arbitrarily, a species was considered common if a total of $\mathbf{1 0}$ or more individuals were recovered from the manure samples and rare if fewer were recovered. More than 60 common species were recovered (Table 1). Carcinops pumilio (Erichson) and Alphitobius diaperinus (Panzer) were consistently and by far the most abundant species in all 3 regions; apparently, $C$. pumilio was the best-adapted predator for the habitat, and $A$. diaperinus the best-adapted scavenger. Gnathoncus nanus (Scriba) was the next most common species, followed by the Aleocharinae (a group of at least 5 species, excluding the 2 species of Aleochara, which were treated as a
Table 1. Species and relative abundance of common (10 or more individuals/species) adult Coleoptera collected from poultry manure in caged-layer houses in North Carolina. Numbers in parentheses denote no. individuals/species or group collected from 1049 manure samples (1.9-2.5 liter each) during Apr.-Nov., 1977. Coleoptera collected overwinter in Jan. (J) and Mar., (M) 1978 are indicated as mean no. adults (A) or larvae (L) per 5-7 liter manure sample (50 samples from 9 farms).

\section{ANTHICIDAE}

Anthicus cervinus LaFerte (33)

A. ephippium LeConte (16)

A. floralis (Linn.) (159) J-0.2A

A. formicarius (Goeze) (33)

A. lutulentus Casey (33)

\section{CUCUIIDAE}

Silvaninae:

Ahasverus advena (Waltl) (470) J-0.3A

Cucujinae:

Cryptolestes sp. (187)

\section{DERMESTIDAE}

Dermestes ater DeGeer (183) J-0.3A

D. maculatus DeGeer (69)

\section{HISTERIDAE}

Abraeinae:

Acritus fimetarius LeConte (29) J-0.1A

Dendrophilinae:

Carcinops pumilio (Erichson) (42003) J-6.6A, 0.8L; M-3.2A, $0.2 \mathrm{~L}$

Dendrophilus xavieri Marseul (566) J-5.2, 0.1L; M-0.1A, $0.1 \mathrm{~L}$

Histerinae:

Hister abbreviatus $\mathrm{F}$. (33)

H. coenosus Erichson (24)

Margarinotus merdarius Hoffman (13) J-0.5A; M-0.2L

Saprininae:

Gnathoncus nanus (Scriba) (1418) J-32.A, 0.1L; M-1.9A, $0.1 \mathrm{~L}$

Saprinus subnitescens Bickhardt (17)

Euspilotus (Hesperosaprinus) sp. (74)

\section{HYDROPHILIDAE}

Cercyon lateralis (Marsham) (72)

C. praetextatus (Say) (15)

C. quisquilius (L.) (19)

\section{MYCETOPHAGIDAE}

Litargus balteatus LeConte (275)

L. didesmus (Say) (17)

L. sexpunctatus (Say) (17)

Typhaea stercorea (L.) (133) J-0.2A

NITIDULIDAE

Carpophilus lugubris Murray (103)

C. marginellus Motschulsky (27)

C. pilosellus Motschulsky (123)

PTILIIDAE (34)

Acratrichus sp.

Smicrus sp.

\section{RHIZOPHAGIDAE}

Monotoma americana Aube (642) J-0.2A

$M$. fulvipes Melsheimer (29)

$M$. longicollis Gyllenhal (88)

$M$. picipes Herbst (29)

\section{SCARABAEIDAE}

Aphodiinae:

Aphodius granarius (L.) (12)

A. lividus (Olivier) (34)

Ataenius spretulus (Haldeman) (12) 
Table 1.-Continued

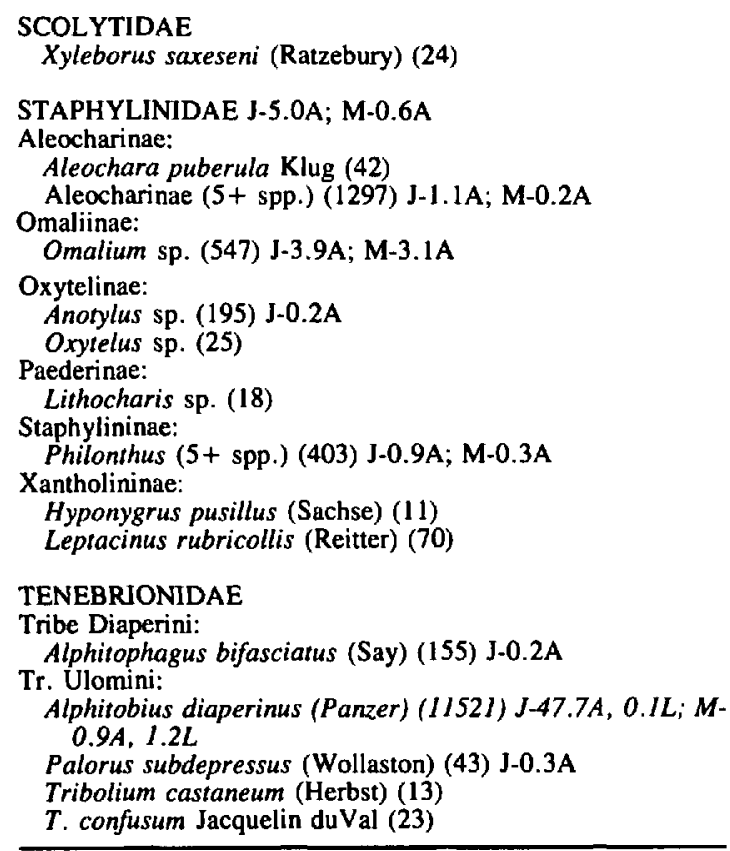

group because of present taxonomic problems (Arnett 1973))

An undescribed species of histerid of the genus Euspilotus (Hesperosaprinus) was found; Wenzel (pers. comm.) places it near modestior Marseul and modestus Erichson. It was found only in the Coastal Plain, except for 2 specimens found in the Piedmont.

Many others (59+) were rare (often represented in the samples only by a single specimen) and some were obviously present in the manure by accident. The rare species collected (no. specimens follows species in parentheses) were as follows: Family Anthicidae: Notoxus monodon F. (4), Vacusus vicinus (LaFerte) (4); Family Anthribidae: Euparinus marmoreus (Olivier) (1); Family Carabidae: Acupalpus sp. (1), Bembidion spp. (3), Bradycellus sp. (1), Clivina sp (1), Elaphropus sp. (1), Harpalus (Pseudophenus) sp. (1), Stenolophus spp. (4); Family Cerylonidae: Aglenus brunneus (Gyllenhal) (1); Family Chrysomelidae; Diabrotica undecimpunctata howardi Barber (1), Gastrophysa cyanea Melsheimer (1); Family Clambidae: Clambus puberulus LeConte (1); Family Cleridae: Necrobia ruficollis (F.) (1); Family Colydiidae: Bothrideres geminatus (Say) (1); Family Cryptophagidae: Cryptophagus sp. (1), Cryptophilus seriatus Casey (1), Atomaria sp. (1); Family Cucujidae: Cathartosilvanus imbellis (L.) (1), Oryzaephilus surinamensis (L.) (9), Silvanus muticus Sharp (1); Family Curculionidae: Hyperodes humilis (Gyllenhal) (9), Listroderes costirostris obliquus (Klug) (5), Sitophilus zeamais Motschulsky (6); Family Dermestidae: Anthrenus verbasci (L.) (1); Family Elateridae: Aeolus mellillus mellillus (Say) (1), Conoderus bellus (Say) (6); Family Heteroceridae: Tropicus pusillus (Say) (1); Family Histeridae: Peranus bimaculatus L. (2), Phelister vernus
Say (3), Gnathoncus communis Marseul (3), Euspilotus (Hesperosaprinus) assimilis Paykull (1), E. (Neosaprinus) scrupularis (LeConte) (6); Family Hydrophilidae: Sphaeridium bipustulatum F. (4); Family Languriidae: Toramus pulchellus LeConte (3); Family Lathridiidae: Holoparamecus floridanus Fall (2), Corticaria sp. (3): Family Melyridae: Collops quadrimaculatus Fab. (1); Family Nitidulidae: Conotelus stenoides Murray (3), Epuraea labilis Erichson (1); Family Orthoperidae Orthroperus sp. (1), Sericoderus sp. (1); Family Ptinidae: Ptinus variegatus Rossi (8); Family Scarabaeidae: Ataenius languidus Schmidt (1), Dyscinetus morator (F.) (1), Onthophagus hecate Panzer (2), O. pennsylvanicus Harold (1), Trox suberosus F. (1); Family Staphylinidae: Aleochara sp. (1), Lispinus (Pseudolispinodes) sp. (2), Carpelimus sp. (3), Platystethus americanus Erichson (3), P. spiculus Erichson (4), Lobrathium sp. (1), Belonuchus formosus Gravenhorst (4), Creophilus maxillosus L. (4); Family Tenebrionidae: Gondwanocrypticus obsoletus (Say) (1), Tenebrio molitor L. (1), Palorus ratzeburgi (Wisseman) (2).

\section{Regional and Seasonal Comparisons}

Fig. 1-3 show the regional and seasonal populations of the adults and larvae of the 3 most abundant species recovered. C. pumilio (Fig. 1) adults were more numerous than larvae during most of the sampling period (Apr. - Nov.). The adults were numerous from May - Oct. in all regions but were most numerous (60 or more/manure

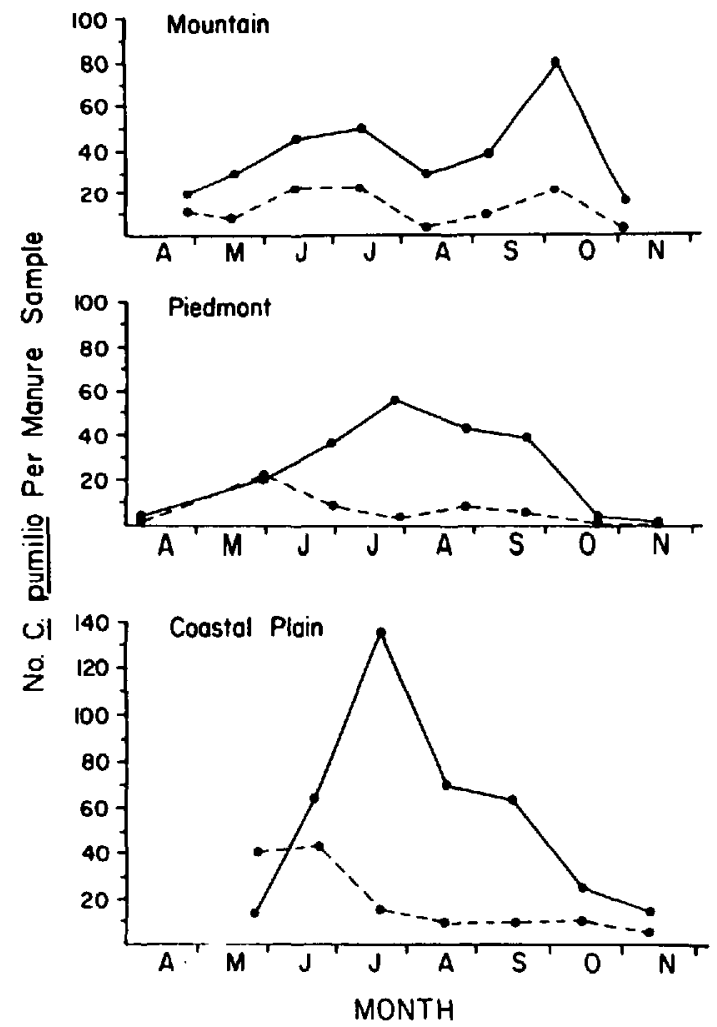

Fig. 1-Mean no. Carcinops pumilio adults (solid line) and larvae (broken line) per poultry manure sample from 3 regions (Mountains, Piedmont, Coastal Plain) of North Carolina, Apr.Nov., 1977. 

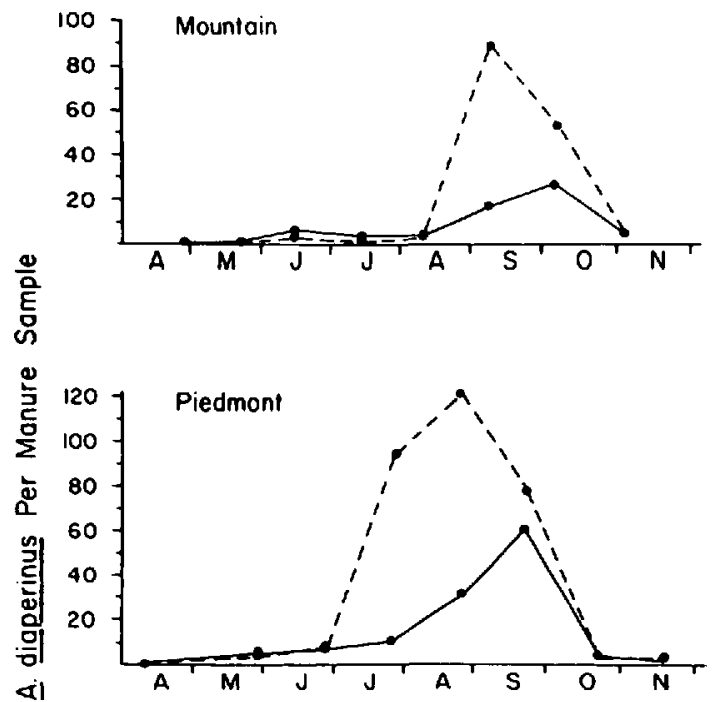

운

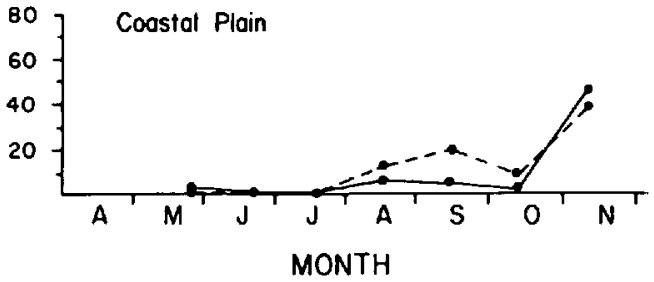

FiG. 2-Mean no. Alphitobius diaperinus adults (solid line) and larvae (broken line) per poultry manure sample from 3 regions (Mountains, Piedmont, Coastal Plain) of North Carolina, Apr.-Nov., 1977.

sample) in the Coastal Plain in June - Aug. A. diaperinus (Fig. 2) larvae were usually more numerous than the adults and both life stages were most abundant in samples from the Piedmont region and least abundant in the Coastal Plain. $A$. diaperinus was present later in the season than $C$. pumilio being recovered mostly in July Sept. in the Piedmont, in Sept. - early Oct. in the Mountain region and in Nov. in the Coastal Plain. G. nanus (Fig. 3) adults were usually more abundant than the larvae, although both life stages were present in low numbers, especially in the Coastal Plain. The adults were most numerous early in the season (May - June) in the Piedmont and Mountain regions.

The population curves were compared among the regions using 3 parameters:

(1) Mean area under the curve, estimated by:

$\Sigma$ (mean value on farm i) (no. of days in sampling period) (no. of farms)

(2) Mean population peak, estimated by:

$\Sigma$ (max. no. of individuals/sample on farm i) (no. of farms)

This mean population peak is not the same as the peak shown in the graph of the population curve, which is merely the mean of all the samples taken on a given date; the peak considered here is the highest number of individuals on a given farm, regardless of the date on which it occurred.

(3) Mean date of the peak occurred on farm i: $\Sigma$ (day no. when peak occurred on farm i) (no. of farms)

(where days have been numbered 1-365).

These parameters were compared among the regions for the equal sampling times during May - Nov. (Table 2). Using Duncan's multiple range test, the mean area under the population curve for $C$. pumilio larvae differed significantly among the regions with a greater area for the Coastal Plain than for the Piedmont and the Mountain region being intermediate, not differing significantly from the other 2 regions. The other comparisons were not significant due to the considerable variation among farms and between houses within each region. The sources of variation were analyzed and details are available (Pfeiffer 1978). Major findings were as follows. For both adults and larvae of $C$. pumilio, A diaperinus and $G$. nanus the most consistent source of variation in numbers collected was the farm $\times$ month interaction, i.e., the farms were significantly different $(P<0.01)$ from each other when sample date was considered. The avg numbers of adults and larvae of $C$. pumilio per farm for the entire season, however, were significantly $(P<0.01)$ different among the farms in the
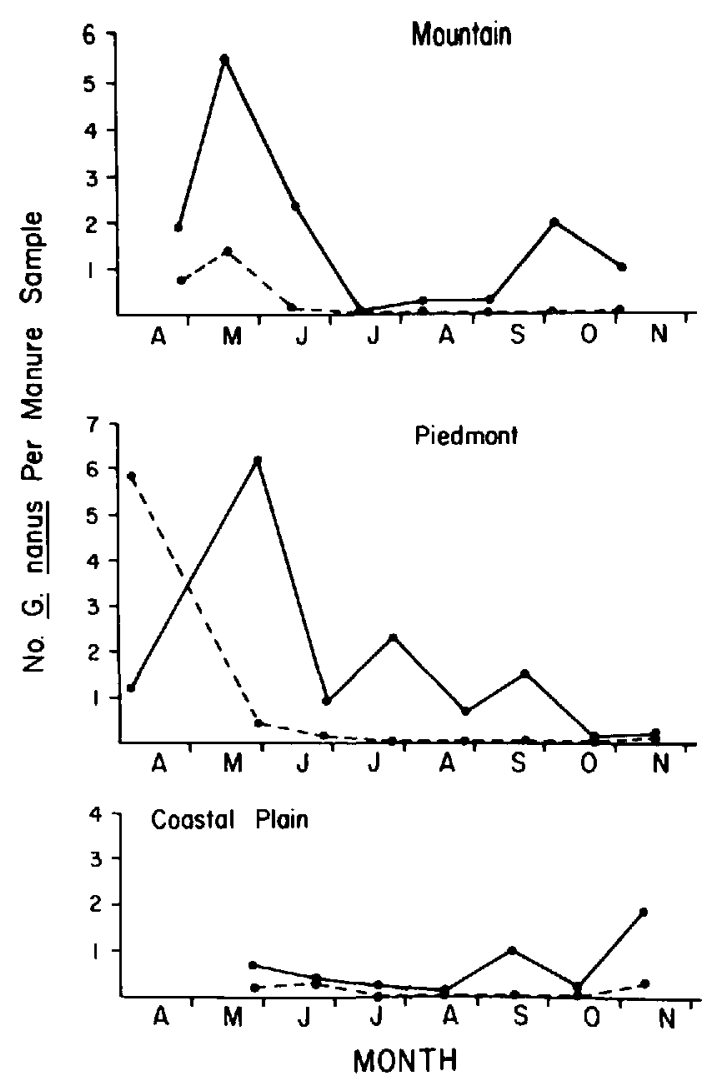

FIG. 3-Mean no. Gnathoncus nanus adults (solid line) and larvae (broken line) per poultry manure sample from 3 regions (Mountains, Piedmont, Coastal Plain) of North Carolina, Apr.Nov., 1977. 
Table 2.-Regional comparisons of the 3 most common Coleoptera recovered from poultry manure based on 3 parameters: mean area under population curve, mean height of population peak, and mean date of peak (see text for explanations of parameters).

\begin{tabular}{|c|c|c|c|}
\hline Species \& stage & $\begin{array}{c}\text { Mean area } \\
\text { under curve }\end{array}$ & $\begin{array}{c}\text { Mèan } \\
\text { peak }\end{array}$ & $\begin{array}{l}\text { Mean date } \\
\text { of peak }\end{array}$ \\
\hline \multicolumn{4}{|c|}{ Carcinops pumilio adults: } \\
\hline Mountain & 6783.7 & 352,8 & Jul 28 \\
\hline Piedmont & 4819.9 & 159.8 & Aup 7 \\
\hline Coastal Plain & 9213.1 & 334.0 & Jul 19 \\
\hline \multicolumn{4}{|c|}{ Carcinops pumilio larvae: } \\
\hline Mountain & 2362.6 & 131.0 & Jul 23 \\
\hline Piedmont & 1199.9 & 102.6 & July 10 \\
\hline Coastal Plain & 2940.0 & 161.0 & Jul 8 \\
\hline \multicolumn{4}{|c|}{ Alphitobius diaperinus adults } \\
\hline Mountain & 1328.3 & 119.4 & Aug 3 \\
\hline Piedmont & 2859.5 & 286.6 & Sep 4 \\
\hline Coastal Plain & 1475.0 & 281.8 & Sep 24 \\
\hline \multicolumn{4}{|c|}{ 4lphitabius diaperinus larvae: } \\
\hline Mountain & 3282.0 & 647.6 & Sep 17 \\
\hline Piedmont & 7486.7 & 575.6 & Aug 18 \\
\hline Coastal Plain & 1831.2 & 152.6 & Sep 20 \\
\hline \multicolumn{4}{|c|}{ Gnathoncus nanus adults: } \\
\hline Mountain & 240.0 & 13.6 & May 31 \\
\hline Piedmont & 311.0 & 24.4 & Jul 26 \\
\hline Coastal Plain & 94.1 & 8.4 & Sep 13 \\
\hline \multicolumn{4}{|c|}{ Gnathoncus nanus larvae: } \\
\hline Mountain & 37.2 & 10.2 & May 20 \\
\hline Piedmont & 16.9 & 10.4 & Jun 28 \\
\hline Coastal Plain & 13.4 & 2.0 & Aug 30 \\
\hline
\end{tabular}

Mountains but not $(P<0.05)$ in the Piedmont and Coastal Plain. For $A$. diaperinus the avg numbers of adults and larvae for the entire season were significantly $(P<0.01)$ different among the farms in the Mountains, for only the adults $(P<0.05)$ in the Piedmont and only the larvae $(P<0.01)$ in the Coastal Plain. For $G$. nanus the avg numbers of only the adults for the entire season were significantly $(P<0.05)$ different among the farms in the 3 regions. The numbers of this species were, of course, much lower than for the other 2 species.

This large variation reflected factors such as (1) differences in cultural practices (manure removal times, manure dryness) at different farms within the same region and among houses on the same farm, (2) different types of houses in different regions, and (3) sampling error.

\section{Diversity Comparison}

Beetle diversity among regions was compared using 5 indices of diversity (Poole 1974, Sager and Hasler 1969, Pielou 1969): Number of groups encountered in a region, Margalef's D, Simpson's D, the Shannon-Weaver Index $\left(\mathrm{H}^{\prime}\right)$, and Pielou's J'. "Species diversity" was not considered per se, because in the calculation of Simpson's $\mathrm{D}, \mathrm{H}$ ', and $\mathrm{J}$ ', some groups were considered as genera (Philonthus spp., Monotoma spp., Cercyon spp., and Ataenius spp.) or families (Anthicidae, Mycetophagidae, Nitidulidae, and Ptiliidae). Only adults were considered.

The results of the diversity tests are shown in Table 3. The values of $\mathrm{H}^{\prime}$, as well as those for $\mathrm{J}$ ', were significantly different $(P<0.01)$ in the 3 regions. The Piedmont had the highest overall diversity, species richness and equitability, followed by the Coastal Plain, and thirdly, by the Mountain. Since this was a survey, caution must be used in ascribing cause and effect to the phenomena observed; but there are several possible reasons (not mutually exclusive) which may at least partially account for the differences in beetle diversity. One of these is manure dryness. Manure at a given farm may have a moisture level more conducive to beetle populations (due to properly maintained watering systems and better drainage). Spilled poultry feed (crushed grain, etc.) may increase beetle diversity by increasing heterogeneity and nutrient content of the manure (increasing diversity at the bottom of a food pyramid). Cultural practices on a farm, i.e., manure removal schedules, could also affect beetle diversity. Farms with manure removed frequently would not have the opportunity to

Table 3.-Comparison of beetle fauna in poultry manure of caged-layer houses in 3 regions of North Carolina using 5 indices of diversity.

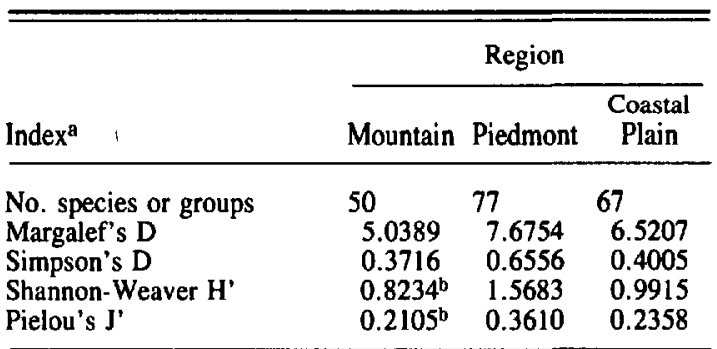

- Margalef's $D=(s-1) / \ln N$, where $s$ is the no. of species; $N$ is the total no. of individuals. Simpson's $D=1-\Sigma_{1}\left(n_{1}-1\right) / N(N-1)$, where $n_{1}$ is the no. of individuals in the $i_{\mathrm{bn}}$ species; $N$ is the toral no. of individuals (Poole 1974). ShannonWeaver $H^{\prime}=-\Sigma_{p_{1}}$ in $p_{1}$, where $p_{1}$ is the proportion of the community in the $i^{\text {th }}$ Weaver $H^{\prime}=-\Sigma_{1}$ in $p_{1}$, where $p_{1}$ is the proportion of the comm
species. Pielou's $J^{\prime}=H^{\prime} / h_{n} s$, where $H^{\prime}$ and $s$ are defined above.

species. Pielou's $\mathrm{J}^{\prime}=\mathrm{H}^{\prime} / \mathrm{h} \mathrm{s}$, where $\mathrm{H}^{\prime}$ and $\mathrm{s}$ are defined above.
"Values of the index were significantly different among the 3 regions $(P>0.01$, t test) (Poole 1974) 
develop a diverse beetle fauna. The Mountain had the lowest beetle diversity, and also had the highest number of farms (3) which had manure removed during this study (including one farm, which was cleaned every 34 wk).

There was no indication of climatological effects on the variations among regions. According to climatological data for the period from Apr. to Nov., 1977, the greatest range in average temperature among the regions was in Nov., and was less than $4^{\circ} \mathrm{C}$. However, variation in daily temperature or degree-days could also be important. Climatological effects would be mitigated by the fact that the beetles live in a sheltered environment; the poultry house offers protection and the manure itself is a heat source.

\section{Comparisons Between Types of Houses}

The numbers of adults and larvae of $C$. pumilio and $A$, diaperinus recovered from the narrow and high-rise types of houses were compared using data from 2 farms (in the Piedmont) which each had both types of structures. The seasonal population curves are shown in Fig. 4 and 5 . The comparisons were made using the same 3 parameters as were used in the among-region comparisons (area under the population curve, peak of the curve, and date of the peak). Neither $C$. pumilio nor $A$. diaperinus differed between the 2 house types in mean area under the population curve or in the size of the population peak. However, the larvel population of $A$. diaperinus did peak significantly earlier in the high-rise (July 26) than in the narrow houses (Aug. 25).

Diversity was also compared between the 2 house types, using number of groups encountered, Margalef's D, Simpson's D, the Shannon-Weaver Index $\left(\mathrm{H}^{\prime}\right)$, and Pielou's J' (Table 4). The narrow houses had higher overall diversity, species richness and equitability than the high-rise houses. The greater beetle diversity in the narrow houses was probably due to the manure being drier and more heterogeneous (in moisture and texture). This greater environmental heterogeneity makes more niches available for exploitation.

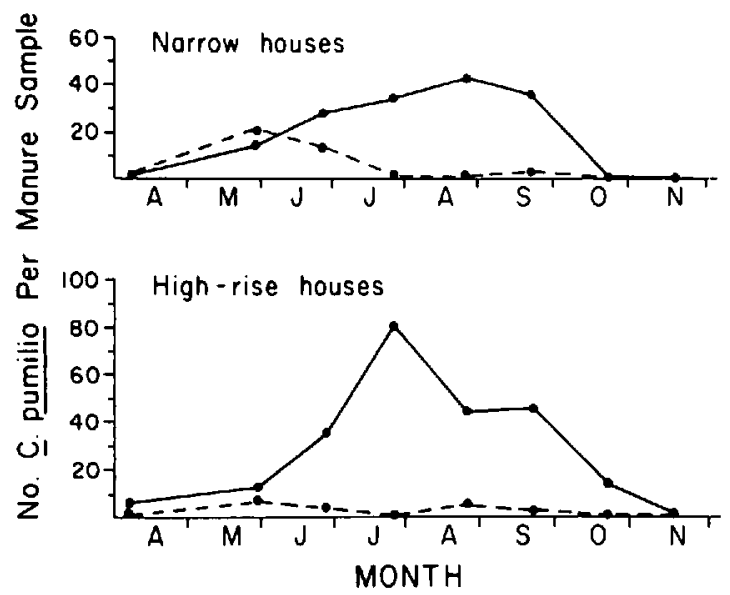

Fig. 4.-Mean no. Carcinops pumilio adults (solid line) and larvae (broken line) per poultry manure sample from narrow and high-rise types of caged-layer houses. Apr.-Nov., 1977.

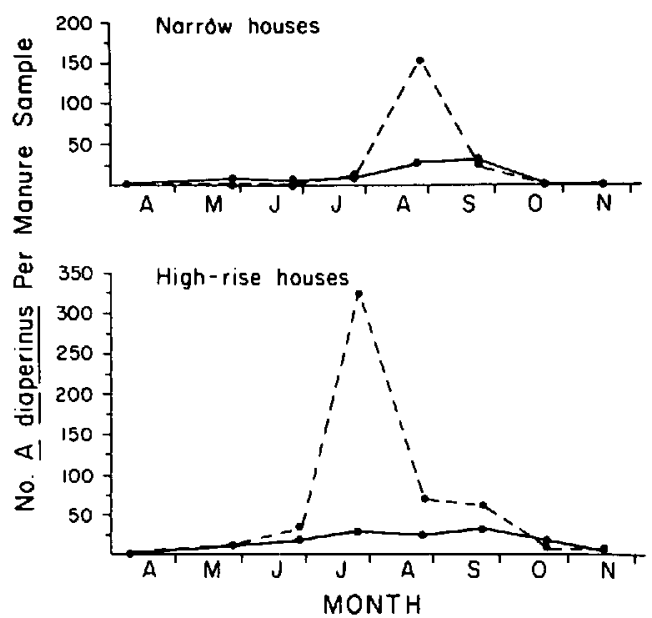

FIG. 5-Mean no. Alphitobius diaperinus adults (solid line) and larvae (solid line) and larvae (broken line) per poultry manure sample from narrow and high-rise types of caged-layer houses, Apr.-Nov., 1977.

\section{Overwintering Forms}

The types and numbers of Coleoptera found in poultry manure in Jan. and Mar. are indicated in Table 1. Histerids and staphylinids were present both as adults and larvae, with the adults usually being more common. This was basically the same relation between adults and larvae as seen in the Apr. - Nov. survey. C. pumilio, $A$. diaperinus, and $G$. nanus were recovered in all 3 regions with adults more common than the larvae.

A noteworthy observation was the occurrence of 2 species in numbers that were high relative to the rest of the overwintering beetles; these were Omalium sp. and Gondwanocrypticus obsoletus (Say). They were very rare in the Apr.-Nov. survey, occurring late in the season, and were highly localized. Omalium sp. was found only on the one farm (in the Piedmont), in Nov., averaging 54.7/sample. Only a single specimen of $G$. obsoletus was found in Sept., but several were found in Jan. This demonstrates the possibility of species being more common in winter than in summer.

\section{Potential Role of Beetles in Fly Control}

Peck (1969) in laboratory studies showed that Philonthus politus L., P. sordidus Gravenhorst, Creophilus maxillosus L., Margarinotus merdarius Hoffman, and

Table 4.-Comparison of beetle fauna in poultry manure of 2 types of caged-layer houses in North Carolina using 5 indices of diversity.

\begin{tabular}{lcc}
\hline \hline & \multicolumn{2}{c}{ House type } \\
\cline { 2 - 3 } Index $^{\mathrm{a}}$ & Narrow & High-rise \\
\hline No. Species or groups & 33 & 20 \\
Margalef's D & 4.0083 & 2.2863 \\
Simpson's D & 0.6291 & 0.5623 \\
Shannon-Weaver H' & $1.3620^{\mathrm{b}}$ & 1.0122 \\
Pielou's J' & $0.3895^{\mathrm{b}}$ & 0.3379 \\
\hline
\end{tabular}

- See table 3 for definitions.

D Values of the index were significantly different between the 2 house types ( $P$ $>0.01, t$ test) (Poole 1974). 
Carcinops pumilio feed on the immature stages of $M$. domestica and Fannia femoralis (Stein). The most voracious predator was $C$. maxillosus (40.8 immature flies destroyed) with most of the predation on the fly pupae. However, this is of limited impact due to the low numbers of $3 \mathrm{C}$. maxillosus in the manure. The high predation rate of such a small beetle as $C$. pumilio $(2.5 \mathrm{~mm})$ was also noted ( 30.3 immature flies destroyed/adult beetle, 27.0/larva); Peck considered it comparable in importance to Macrocheles muscaedomesticae (Scopoli), a predaceous mite shown to feed upon fly eggs in manure (Axtell 1967).

The common species found in poultry manure and shown to be predaceous on immature $M$. domestica by Toyama and Ikeda (1976b) were Philonthus longicornis Stephans, and four histerids, Paromalus lautus Zimmerman, Saprinus fimbriatus LeConte, Atholus rothkirchi Bickhardt, and $S$. lugens Erichson. One of the other common species, Dactylosternum abdominale Fab. (a sphaeridiine hydrophilid. as are those in Table 1) was found to feed on young fly larvae only to a small degree; however, the full impact of this species was not shown because the adults of this family are generally scavengers, while the larvae are primarily predaceous (Arnett 1973). Carcinops sp., which was only occasionally found, consumed 31.9 eggs and 3.4 first-stage larvae. This is comparable with the results of Peck (1969).

Aleochara puberula Klug is an ectoparasite within the puparia of several species of cyclorrhaphan Diptera. Toyama and Ikeda (1976a) recovered this staphylinid from $M$. domestica on poultry, dairy, and hog farms. The adults are predaceous on fly eggs and larvae.

Predaceous beetles, especially histerids and staphylinids, are important naturally-occurring fly control agents in poultry houses. From our study and the studies previously cited, it appears that the species of predaceous beetles in poultry manure are similar in most localities and the principal species are Carcinops pumilio, Alphitobius diaperinus, and Gnathoncus nanus. Because of the large populations of these species, especially $C$. pumilio, and the numbers of fly eggs eaten by both larvae and adults, these beetles cause a considerable portion of the natural mortality in the fly population around poultry houses. Therefore, a fly management program should include measures to enhance the beetle population (Axtell 1970ab). Reduction in the densities of fly pupa due to predation by beetles (and by other predators) on the earlier stages of the flies will enhance the effectiveness of parasites which attack only the pupal stage (Legner 1971). Rearing and releasing beetles appears not very practical due to cannibalism and the lack of satisfactory rearing methods. However, if economical and efficient rearing methods could be developed, it would be of great benefit, because development of some species of beetles does not take much longer than that of the hymenopterous parasites currently being reared and released in some fly management programs. For example, $C$. pumilio requires $26.5-34.5$ days from oviposition to ecolsion (Smith 1975), while Spalangia endius Walker and Muscidifurax raptor Girault \& Sanders, pteromalid parasites, require an average of 18-22 days (Ables et al. 1976, Legner and Gerling 1967, Morgan et al. 1978).

\section{Acknowledgment}

We thank the following specialists who identified series of specimens; D. M. Anderson (Scolytidae, larvae of Mycetophagidae, Anthicidae, and Monotominae), W. F. Barr (Cleridae), W. A. Connell (Nitidulidae), T. L. Erwin (Carabidae), R. D. Gordon (Coccinellidae, Orthroperidae, and Scarabaeidae), L. H. Herman (Staphylinidae), E. R. Hoebeke (Staphylinidae), J. M. Kingsolver (Cerylonidae, Clambidae, Colydiidae, Cryptophagidae, Dermestidae, Heteroceridae, Languriidae, Lathridiidae, Melyridae, Mycetophagidae, Ptiliidae, and Rhizophagidae), I. Moore (Staphylinidae), A. Smetana (Staphylinidae), P. J. Spangler (Hydrophilidae), T. J. Spilman (Cucujidae, Elateridae, Ptinidae, and Tenebrionidae), R. L. Wenzel (Histeridae), F. G. Werner (Anthicidae), R. White (Anthribidae and Chrysomelidae), and D. R. Whitehead (Curculionidae).

We thank R. J. Monroe, of the NCSU Dept. of Statistics for advice on some of the statistical analyses, Mr. J. P. Geaghan, NCSU Dept. of Zoology, for use of his GENPLOT computer program to construct the graphs of the population curves, and D. A. Rutz and T. D. Edwards for assistance in the field work.

\section{REFERENCES CITED}

Ables, J. R., M. Shepard, and J. R. Holman. 1976. Development of the parasitoids Spalangia endius and Muscidifurax raptor in relation to constant and variable temperature: Simulation and validation. Environ. Entomol. 5: 329-32.

Arnett, R. H. 1973. The beetles of the United States: A manual for identification. American Entomological Institute. Fourth Printing. $1112 \mathrm{pp}$.

Axtell, R. C. 1967. Macrochelidae (Acarina: Mesostigmata) as biological control agents for synanthropic flies. Proc. 2nd Intern. Cong. Acarol. 401-16.

1970a. Integrated fly-control program for caged-poultry houses. J. Econ. Entomol. 63: 400-5.

$1970 \mathrm{~b}$. Fly control in caged-poultry houses: Comparison of larviciding and integrated control programs. Ibid. 63: $1734-7$.

Barr, A. J., J. H. Goodnight, J. P. Sall, and J. T. Helwig. 1976. A user's guide to SAS 76. SAS Institute, Inc., Raleigh. $329 \mathrm{pp}$.

Helwig, J. T., ed. 1977. SAS supplemental library user's guide. SAS Institute, Inc., Raleigh. 171 pp.

Legner, E. F. 1965. Un complejo de los artrópodos que influyen en los estadios juveniles de Musca domestica L. en Puerto Rico. Carib. J. Sci., Mayaguez. 5; 109-15.

1971. Some effects of the ambient arthropod complex on the density and potential parasitization of muscoid diptera in poultry waste. J. Econ. Entomol. 64: 111-5.

Legner, E. F., and D. Gerling. 1967. Host-feeding and oviposition on Musca domestica by Spalangia cameroni, $\mathrm{Na}$ sonia vitripennis and Muscidifurax raptor (Hymenoptera: Pteromalidae) influences their longevity and fecundity. Ann. Entomol. Soc. Am. 60: 678-91.

Legner, E. F., and G. S. Olton. 1970. Worldwide survey and comparison of adult predator and scavenger insect populations associated with domestic animal manure where livestock is artificially congregated. Hilgardia 40: 225-66.

Legner, E. F., G. S. Olton, R. E. Eastwood, and E. J. Dietrick. 1975. Seasonal density, distribution and interactions of predatory and scavenger arthropods in accumulat- 
ing poultry wastes in coastal and interior Califomia. Entomophaga 20: 269-83.

Morgan, P. B., G. C. LaBrecque, and R. S. Patterson. 1978. Mass culturing the microhymenopteran parasite Spalangia endius (Hymenoptera: Pteromalidae). J. Med. Entomol. 14: 671-3.

Peck, J. H. 1969. Arthropod predators of immature Diptera developing in poultry droppings in northern California. Part II. Laboratory studies on feeding behavior and predator potential of selected species. Ibid. 6:168-71.

Peck, J. H., and J. R. Anderson. 1969. Arthropod predators of immature Diptera developing in poultry droppings in northern California. Part I. Determination, seasonal abundance and natural cohabitation with prey. Ibid. 6:163-7.

Pfeiffer, D. G. 1978. The Coleoptera of poultry houses in North Carolina. M. S. thesis, N. Carolina State Univ. Raleigh 106 pp.
Pielou, E. C. 1969. An Introduction to Mathematical Ecology. Wiley-Interscience, NY 286. pp.

Poole, R. W. 1974. An Introduction to Quantitative Ecology. McGraw-Hill Book Company, NY 532 pp.

Sager, P. E., and A. D. Hasler. 1969. Species diversity in lacustrine phytoplankton. I. The components of the index of diversity from Shannon's formula. Am. Nat. 103: 519.

Smith, K. A. 1975. Observations on the life history, ecology and behavior of Carcinops pumilio (Erichson). M.S. Thesis, Univ. of New Hampshire, Durham. 52 pp.

Toyama, G. M., and J. K. Ikeda. 1976a. An evaluation of fly breeding and fly parasites at animal farms on leeward and central Oahu. Proc. Haw. Entomol. Soc. 22: 353-68.

Toyama, G. M., and J. K. Ikeda. 1976b. An evaluation of fly predators at animal farms on leeward and central Oahu. Ibid. 22: 369-79. 